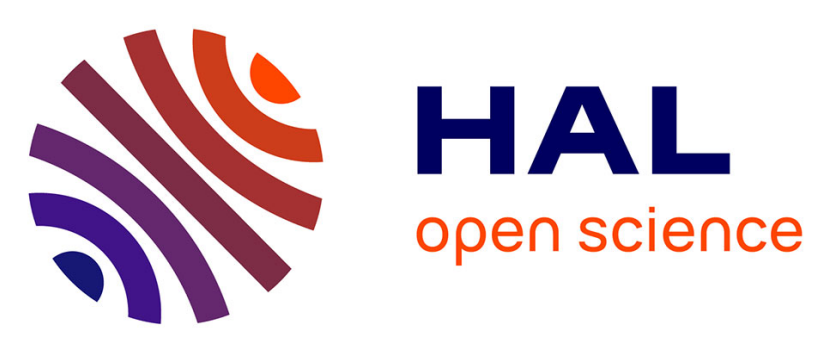

\title{
Limits to the construction of a community-based open innovation network and implications for specialisation of a small urban area
}

Martine Gadille, Alena A. Siarheyeva

\section{- To cite this version:}

Martine Gadille, Alena A. Siarheyeva. Limits to the construction of a community-based open innovation network and implications for specialisation of a small urban area. International Journal of Knowledge-Based Development , 2014, 5 (2), pp.152-172. 10.1504/IJKBD.2014.063992 . hal02094453

\section{HAL Id: hal-02094453 \\ https://hal.science/hal-02094453}

Submitted on 9 Apr 2019

HAL is a multi-disciplinary open access archive for the deposit and dissemination of scientific research documents, whether they are published or not. The documents may come from teaching and research institutions in France or abroad, or from public or private research centers.
L'archive ouverte pluridisciplinaire HAL, est destinée au dépôt et à la diffusion de documents scientifiques de niveau recherche, publiés ou non, émanant des établissements d'enseignement et de recherche français ou étrangers, des laboratoires publics ou privés. 


\title{
Limits to the construction of a community-based open innovation network and implications for specialisation of a small urban area
}

\author{
Martine Gadille* \\ Aix-Marseille Université, \\ CNRS, \\ Laboratoire d'Economie et de Sociologie du Travail, \\ LEST UMR 7317, 35 avenue Jules Ferry, \\ 13626 Aix-en-Provence Cedex 01, France \\ Fax : + 33-(4)-42-26-79-37 \\ E-mail: martine.gadille@univ-amu.fr \\ *Corresponding author
}

\author{
Alena Siarheyeva \\ ISEN-Toulon, \\ Ecole d'ingénieur, \\ ISEN, Maison des Technologies, place Georges Pompidou, \\ 83000 Toulon, France \\ E-mail: alena.siarheyeva@isen.fr
}

\begin{abstract}
The article studies an ICT collaborative project developed in the framework of the regional innovation policy of the PACA region, France. It seeks to gain a better understanding of the evolution of a community-based open innovation network shaped during the project implementation. Conditions for its emergence, construction and stabilisation are discussed from theoretical and practical viewpoints, including governance design and leadership characteristics as well as factors determining collaboration (IPR, timespan and individual characteristics of participants). Community animation style is highlighted as an important ingredient for emergence of innovative ideas from the cognitive resources of the territory, to favour smart specialisation. A longitudinal and qualitative method of observation is used, covering the period from the emergence of the project until its administrative end, with follow-up of emerged innovative enterprises. A participative research approach is adopted to collect diverse data (minutes of meeting, working documents, etc.) and to conduct interviews during the project.
\end{abstract}

Keywords: living lab; community-based open innovation network; governance; ICT; community organiser, animator.

Reference to this paper should be made as follows: Gadille, M. and Siarheyeva, A. (2014) 'Limits to the construction of a community-based open innovation network and implications for specialisation of a small urban area', Int. J. Knowledge-Based Development, Vol. 5, No. 2, pp.152-172. 
Biographical notes: Martine Gadille is a Researcher in Business Administration at the University of Aix-Marseille. She gained her first degree and $\mathrm{PhD}$ in Economics at the University of Aix-Marseille. Her research is focused on the governance of innovation, employment and skills dynamics in clusters and knowledge management within SMBs. She is a university Senior Lecturer as well as a speaker at national and international conferences and author of over 50 academic and practitioner papers.

Alena Siarheyeva is a Research Fellow in Business Administration at ISEN-Toulon and an Associate Researcher at the University of Aix-Marseille. She gained her first degree and $\mathrm{PhD}$ in Economics at the University of Aix-Marseille. She also works at TELUQ at the University of Quebec, as a Visiting Research Fellow. Her research is focused on collective creativity processes, governance of collaborative and territorial projects and innovation within cultural activities. She is a Lecturer for engineering students as well as a regular speaker at national and international conferences and author of a dozen academic and practitioner papers.

This paper is a revised and expanded version of a paper entitled Limits to the construction of an open innovation network: the case of pre-setup of a living lab in a small urban area presented at 8th the International Forum on Knowledge Assets Dynamics (IFKAD), Zagreb, Croatia, 12-14 June 2013.

\section{Introduction}

This article studies a collaborative project of pre-set up of an open innovation lab developed in the framework of the regional innovation policy tool 'PACA Labs' of the PACA region, France ${ }^{1}$. The project analysed here is carried out by a group of actors sharing a common language about and a vision of the relationship between digital development and societal transformations. In this sense, the initiative is defined as a community-based open innovation network. The focus is on the functioning of this form of organisation with no pre-defined aim, leading stakeholders to step outside the prescriptive framework of their employment relationship.

The objective of the research is to better understand the evolution of the community-based open innovation network shaped during the project implementation. The conditions for its emergence, construction and stabilisation are analysed from theoretical and practical viewpoints, including governance design and leadership characteristics as well as factors determining collaboration (IPR, timespan and individual characteristics of participants). Community animation style is highlighted as an important ingredient for emergence of innovative ideas from the cognitive resources of the territory, to favour its smart specialisation.

The article is organised as follows: Section 2 sets the theoretical framework. Section 3 describes the context, defines the evolution phases of the initiative under analysis and the methodological approach. Section 4 examines the evolution of the governance design and the form of leadership; it also lists additional important factors for shaping a community-based open innovation network. Section 5 characterises innovative sub-projects emerged within the network and presents the animation styles that initiated them. Section 6 discusses theoretical, practical and policy implications. Section 7 concludes. 


\section{Theoretical framework}

\subsection{Open innovation networks as tools for smart specialisation}

The main challenge in the smart specialisation process is how "to emphasise the vertical logic of prioritisation (of R\&D activities at regional level) while avoiding the government failures usually associated with the top-down and centralised bureaucratic processes of technology choices and selection" [Foray and Goenaga, (2013), p.3]. It is believed that entrepreneurs are best positioned to discover the domains of innovation in which a region is likely to excel, given its knowledge endowments and production capabilities (ibid.).

This definition of smart specialisation echoes the model of open innovation rooted in the idea that knowledge sharing could serve new developments that would not occur in a situation of exclusive intellectual property (Chesbrough, 2003). The role of users or providers and networks is considered crucial in this mode of innovation. The mainstream model is crystallised in the contributions of Chesbrough and his co-authors: “... open innovation networks comprise suppliers, customers, rival companies, research units of universities, and other institutions that aim to develop breakthroughs in technology, products, and services that can be further commercialised" (Chesbrough and Schwartz, 2007). This approach needs to be complemented to take into account interdependencies of innovators and their embeddedness in communities, because "regions are not simply economic engines but also social communities" [Scott, (1998), p.152]. In this perspective, analysis of smart specialisation within an urban area can be addressed through the lenses of the open innovation network, as defined in organisation theory. In this field, such a type of network of adhocratic form is rooted in a community of practice. In other words, the open innovation network is subsumed under the community-based organisational form (at the level of inter-firm relations) (Adler, 2001; Astley and van de Ven, 1983; Jarvenpaa and Wernick, 2011).

The issue of prioritisation of innovative activities raised by the smart specialisation paradigm involves the issue of governance, i.e., "how local social control is constituted and the nature of organisational structures through which that control is exerted" (Scott, 1998). Support to such communities of interest would reinforce regional peculiarity, in line with smart specialisation objectives. Political action at regional level is expected to provide an authentic arena of political identity and organisation for such communities. Open innovation networks can offer means to acquire fully developed capacities for collective decision-making and action supporting social and economic entrepreneurship, intra-regionally and inter-regionally.

Open innovation networks can be seen as a public policy tool supporting community-based organisational forms where innovators are considered not only from the economic viewpoint but also from income distribution, social and cultural viewpoints. West and O'Mahony define such organisational forms as sponsored communities, by analysing the organisational model of open source communities: a funded open source community is a community where one (or more) entities control the short or long term activity of the former (West and O'Mahony, 2008). Although subject to a form of authority control, this modern collective form of production does not inherit any traditional basis of authority theorised by Weber (paternalistic tradition, impersonal rule of bureaucracy and charisma supporting adhocracy) (O’Mahony and Ferraro, 2007). 


\subsection{Factors influencing construction of a community-based open innovation network}

West and O'Mahony underline three important factors influencing the construction of a community-based innovation network: organisation of production, governance and intellectual property (West and O'Mahony, 2008). In terms of organisation of production, a tacit or explicit aim of such communities is to collectively solve problems by seeking innovative solutions (Saint-Onge and Wallace, 2002). However, their main activity is not necessarily market-oriented and is defined by three characteristics: mutual engagement, joint entrepreneurship and resources pooling and sharing (Wenger, 1998). In any case, to function, these communities need to coordinate interactions that gather a wide range of competences and knowledge bases and constant adaptation to the evolving and cognitive nature of projects. The challenge they face cannot be met by a task team understood in the usual sense of a small, homogeneous and informal group (Heckscher and Adler, 2006).

The issue of organisation of production is also discussed by Jarvenpaa and Wernick, who show paradoxical tensions between open innovation management and management of innovation relying solely on internal resources (Jarvenpaa and Wernick, 2011). The authors underline new skills that project leaders have to develop to manage open innovation. They also show that open innovation is rather a state of mind rather than a model or a process.

The qualities of the project leader can be nuanced drawing on the literature dedicated to community organisers. These contributions are more appropriate for the organisational configuration under study, compared to the literature on structural holes and brokers, focusing rather on career network issues and opportunistic behaviour (Burt 1992; Xiao and Tsui, 2007). Christopher discusses numerous roles community organisers can play (Christopher, 1988). The project leader as community animator encourages, provides direction and guidelines to proceed, helps people to come forward and to have active participation from planning stage to evaluation stage and increases the level of consciousness. The community organiser is defined as an innovator if he/she innovates, performs and improves techniques in the process of community organisation. He/she spurs experiments on new ways and means to find solutions to needs and problems. The community organiser in the role of a catalyst retains his/her identity and promotes people's empowerment, accelerates actions and reactions to achieve desired results. Under such leadership, people gain control over resources and skills in decision-making, increase their response level and become experts in responding to their own needs. The Educator brings to the community the information necessary for coping with problem situations and decision-making, assists in practising new behaviour patterns or skills and teaches through presentation of role models. The facilitator helps the community to express their needs, to identify problems, to explore appropriate strategies, to develop people's capacities to deal with their own problems more effectively. Finally, the community leader in the role of Mediator takes a neutral stance between the parties involved and takes part in settling disputes between members or between the community and external persons.

The leadership issue leads to the issue of governance, more precisely, of the regulation, organisation and coordination of individual actions to produce collective results. Organisation into communities of practice implies prioritisation of cooperation 
defined by cross-prescriptions of rules (Argyris and Schön, 1978), including professional identities (Gherardi, 2001). In traditional theories of organisations, a shared vision of authority is necessary to establish a form of governance (Etzioni, 1959). Some authors' stress that the existence of organisations with no consensus about the form of authority is weakened (Coleman, 1980; Etzioni, 1959; Harrison, 1960). Other contributions provide evidence about difficulties in making exist, developing and managing complexity and decision-taking in organisations with direct form of participation (Johnson and Whyte, 1977; Rothschild and Russell, 1986; Rothschild and Whitt, 1986; Whyte and Whyte, 1988). Control is the key mechanism motivating cooperation among participants who only partially share congruous objectives and only partially agree on common objectives and the behaviours best suited to reach the objectives (Ouchi, 1980).

However, the community system of governance is not subject to legal rules defining employment relationships (West and O'Mahony, 2008). This implies that the professionalism or identities of the community actors are built within an inter-organisational space rather than within the relationship of legitimate authority inside each organisation. Markus emphasises the role of sharing similar cultural values in the process of adjustment of behaviours to the community aims (Markus, 2007). O’Mahony and Ferraro, in their analysis of the community form, show how it blends position of authority within formal social control (O'Mahony and Ferraro, 2007). In short, the literature on open source communities emphasises the notion of a shared vision of authority. However, O'Mahony and Ferraro also show that when community members agree on a shared conception of authority, its implementation can be more costly than that involving control of one party by another (O’Mahony and Ferraro, 2007). Finally, in sponsored communities accountable in terms of project funding and outcomes, tensions may arise between bureaucratic control and democratic participation, as illustrated by the experience of sponsored open source communities (West and O'Mahony, 2008). This issue is similarly discussed in the project management literature. It distinguishes projects characterised by prescribed objectives and results within a company or different partner companies from inter-organisational projects, where stakeholders are not pre-defined nor the governance mode and the types of results.

The last important issue in the construction and functioning of a community-based open innovation network relates to the sharing of intellectual property rights. Literature on sponsored open source communities highlights the fact that tensions about IPR share may arise in such organisational forms of knowledge production. The community members are relatively reluctant towards the participation of external contributors. Fears that donors will take the benefits of the community creation would limit the advantages offered to contributing members. West describes the dilemma that creators inevitably face between the wish to see their technological solution adopted and the fear of misappropriation of the investment benefits by other actors (West, 2003). O'Mahony shows how this tension can be alleviated. When enterprises or sponsored communities create a foundation to support the endeavour of a specific community, content ownership is defined in a way to guarantee unrestricted access to coding to all participants (O’Mahony, 2005). 


\section{Research context and methodological approach}

\subsection{Political context and evolution phases of the project}

The conditions for creation and implementation of the project under study are related to the public policy tool 'PACA Labs'. This is a collective measure of call for proposals launched in 2008 to support experimentations of digital innovation projects within the local territories and in connection with users. The objective of this support scheme is to promote models of 'open innovation' and involvement of local users in the development of new digital technologies and services.

Four main structuring phases of the project under consideration can be distinguished.

\subsubsection{Emergence/start-up involving a restricted number of community participants - the founders}

The idea of the project emerged in November 2010 during an informal meeting of three individuals wishing to run an ICT-oriented project in the PACA region. They all belong to very diverse universes: a representative of a young NGO operating in the sector of development of artistic, cultural and educational multimedia, a consultant for local communities in the area of development of multimedia services integrating open data and a business incubator project manager. In December 2010, they received consent from the regional authorities to draw up a proposal in the framework of axis 3: 'development of an ecosystem' of the PACA Labs policy tool. Two project coordinators were legitimised by this restricted community: the business incubator project manager and the cultural NGO co-director, possessing high technological expertise in city media and having access to a comprehensive network of artists and actors in the cultural milieu. Two new members from academia joined the network at this stage; both possess specific knowledge about the articulation between mediation of knowledge and ICT uses; one of them is also a visual art designer. The project was officially presented in April and approved by local governors in June 2011. A kick-off meeting quickly followed.

The founders had a vision different from the academic and managerial model of open innovation. They were willing to build their initiative on the postulate that co-construction of the design of a collective organisation and/or of artefacts allowing infusion of ideas should be an open process itself. In other words, it should not be $a$ priori determined by project governance; furthermore, it should not necessarily be for-profit. The emergence phase was thus characterised by anchorage in this discourse and by deliberated differentiation from the 'industrial' vision of open innovation. The alternative vision of open innovation shared by the founders and explicitly cited in background papers has its origins in the experiences of hack and technical knowledge share reinforced by the advent of internet and digital (Wathieu, 2007; Cleempoel and Wathieu, 2006). Furthermore, the founders behaved as community of practice members and relied on mutual trust and confidence rooted in the skills of everyone as well in social values of convivial atmosphere and knowledge share and in environmental values.

\subsubsection{Tensions between community members and emergence of a leader}

The founding group believed that the realisation of the collaborative project was essentially related to the organisation of thematic workshops. It implied construction of 
two-level governance: governance of the global (parent) project and organisational design of workshop animation. The workshops were conceived as cross-sectoral and participative, i.e., opened to a large and diverse number of participants from the territory (citizens, SMEs, representatives of non-profit organisations, local authorities and independent intellectual professionals). They were expected to capture and materialise knowledge resources and leadership available within the territory and to serve as a foundation for the innovation lab. Up to February 2012, intensive work involving various local actors capable of organising or animating workshops (human and social science researchers, social workers, professional animators, cultural mediators, independent intellectual professionals) was done to design a methodology and a participation mode for thematic workshops.

Despite the shared vision of open innovation, tensions arose within the collective of founders about whether to organise thematic workshops rather oriented to applications and ICT uses (for example, open data) or to organise consultation workshops to stimulate participating users and citizens to develop a more reflexive and semantic work on the sense of digital in social, economic and educational practices. They did not find a compromise and the two members from academia left the project; the remaining collective requested help from our research team. During this phase, the NGO coordinator abandoned his administrative responsibilities, while keeping his responsibility as the organiser of an experimental workshop. The latter was related to his own initiative of enterprise creation. Following his step-down, the exercise of authority in the parent project was left to one person, the business incubator project manager.

\subsubsection{Leader's decision about empowerment of animators and implementation of workshops}

By early 2012, with the project deadlines approaching, the project coordinator, informed by early research observations, decided to rely on those members of the community who were ready to conduct their workshops. Three animators of thematic workshops were given logistic and conceptual support from the coordinator, while keeping organisational autonomy. Table 1 provides detailed information about the workshops organised.

Table 1 Description of thematic workshops

\begin{tabular}{lcc}
\hline Workshop theme & Number of participants and their profiles & $\begin{array}{c}\text { Number of } \\
\text { workshop } \\
\text { meetings }\end{array}$ \\
\hline $\begin{array}{l}\text { Open data: uses of open data } \\
\text { on the local territory }\end{array}$ & 30 participants & Two \\
Cultural operators $-7 \%$ & Support to enterprises $-11 \%$ \\
NGOs/citizens $-17 \%$ \\
Independent intellectual workers $-11 \%$ \\
Education $-11 \%$ \\
Research $-11 \%$ \\
Local authorities $-14 \%$ \\
Enterprises $-18 \%$
\end{tabular}


Table 1 Description of thematic workshops (continued)

\begin{tabular}{|c|c|c|}
\hline Workshop theme & Number of participants and their profiles & $\begin{array}{c}\text { Number of } \\
\text { workshop } \\
\text { meetings }\end{array}$ \\
\hline \multirow{9}{*}{$\begin{array}{l}\text { ICT and education: think } \\
\text { about learning differently, } \\
\text { outside of school and connect } \\
\text { the learning process to } \\
\text { technological artefacts }\end{array}$} & 12 participants & \multirow[t]{9}{*}{ Two } \\
\hline & Cultural operators - 8\% & \\
\hline & Support to enterprises - $16 \%$ & \\
\hline & NGOs/citizens - 28\% & \\
\hline & Independent intellectual workers - no & \\
\hline & Education - 16\% & \\
\hline & Research - 23\% & \\
\hline & Local authorities - no & \\
\hline & Enterprises - 8\% & \\
\hline \multirow{9}{*}{$\begin{array}{l}\text { City media: creation of an } \\
\text { interactive city map }\end{array}$} & 40 participants & \multirow{9}{*}{$\begin{array}{l}\text { Three plus } \\
\text { many } \\
\text { specific } \\
\text { workshops } \\
\text { with } \\
\text { children }\end{array}$} \\
\hline & Cultural operators/artists - 23\% & \\
\hline & Support to enterprises - $14 \%$ & \\
\hline & NGOs/citizens - 14\% & \\
\hline & Independent intellectual workers - no & \\
\hline & Education - 7\% & \\
\hline & Research - 7\% & \\
\hline & Local authorities - 17\% & \\
\hline & Enterprises - 18\% & \\
\hline
\end{tabular}

During this phase, a question naturally arose about the animation process to create a space for democratic expression and suggestion of ideas by users that will be discussed in Section 5.2.

\subsubsection{Consolidation phase}

This final stage of the project is characterised by consolidation of the two-level governance architecture. The interactive structure of the network evolved from the community form to organisation by project steered by the parent project coordinator. Thematic workshops evolved into sub-project teams involving a restricted number of interested participants. In the open data and city media projects, animators took the leadership over their implementation, including raising funds. In the case of ICT and education, no leader emerged at that time. The parent project coordinator drew up specifications to prepare its future implementation. One of the workshop participants took the lead over this sub-project later. The implementation of the three emerged sub-projects was financially supported by local authorities (municipality, county and region).The time frame necessary for consolidation and implementation of each sub-project was different: three months for the open data sub-project, ten months for the city media sub-project and 18 months for the ICT and education sub-project. 


\subsection{Methodological approach: researchers as co-designers}

The very nature of the involvement of our research team in the project, not only as observers but also as potential co-designers of collaborative projects, raised the issue of creation of collaborative artefacts and interaction between researchers and stakeholders (Jelinek et al., 2008). This perspective of organisational design implies a number of questions. The first set of questions is related to the identity of actors who conceive project organisation and its objectives, normativity (why it should be so?) and legitimation of these actors and of the objectives they define. The second set of questions is about approaches in design that would be the most efficient, would produce beneficial results (beneficial to whom?) and would incur lower costs (constrained by whom?). From the epistemological viewpoint, the scientific approach adopted borrows from the idea of entrepreneurial bricolage, opening the opportunity to various stakeholders to evolve towards a design adapted to them (Sarasvathy, 2004). By contrast, Kripendorff and similar contributions highlight the fact that conception of organisational design would create a space for exploration, largely ignored by researchers in design (Krippendorff, 2006). This type of literature focuses on such notions as artefacts, interfaces, conceptual models of participants and stakeholders and, finally, language acts that can be summarised in one phrase: sense creation.

Nevertheless, these postulates are not sufficient to have an explicit and shared vision of behaviour that researchers should adopt to keep the right distance from other actors, in order to remain relatively neutral with respect to stakeholders, whether represented or not. The contribution of Friedberg in the sociology of action clarifies this point (Friedberg, 1993). Regarding the method of intervention, he stresses the fundamental difference between organisational analysis and organisational diagnosis. Analysis undertaken by research cannot bring any criteria of changes or judgments to the observed actors. To be linked to action, these criteria and judgments can and must be initiated by actors of a system themselves. Organisational diagnosis originates from explicit criteria and standards based on a real effort of autonomous self-reflexivity of the system actors with regards to analysis. When doing this, actors build their capacity for reorientation and re-design of the system and lay down the basis for the emergence of actionable knowledge. Knowledge derived from analysis is transformed to serve action.

The epistemology of the current approach and its procedural vision contingent on organisational change relies on the distinction between analysis undertaken by researchers and diagnosis conducted by actors and contributes to a collective process of normalisation. Although this approach is rooted in the notion of a system, or an organised action, pre-existing the search for organisational change, it had already brought into evidence the principles borrowed from design research. The contribution of the latter is based on the idea that researchers may have to intervene in the process of creation and design of an organisation established outside settled structures such as the enterprise, public administration or the non-profit organisation. This endeavour may ultimately in fine 'not make a system' in the sense that the games and players involved in it are too unstable and fail to find a consensus about meta-rules. The logic of intervention would focus lesson system change and more on design capacity-building. In other words, intervention would centre on construction and stabilisation of an open system of actors, of the 'network node' type, in an open network of innovation.

In this type of organisation, the notion of learning cannot, in our view, be restricted to only one social dimension of actors. It is not possible to differentiate structural analysis 
of social relations determining conflicts and that of individual behaviour from analysis of practical, experience-based and subjective 'responses', the contributions of individuals to society construction. There is a recursive relation implying that society produces individuals who determine society. Social determinism and psychic conditioning are plural, heterogeneous and contradictory forces impelling subjects to try to create coherence and unity where incoherence and diversity dominate (Gaulejac, 2008). The implication for the current methodological frame work is that it is important to complement the social dimension of the analysis with the psychic dimension of individuals, as suggested by clinical sociology. The main postulate of this approach is that one should analyse in relative autonomy social processes and mental processes but also connections, interactions and linkages between these two spheres. The so-called 'social' unconscious intertwines with the so-called 'psychic' unconscious; they are not fully differentiated. Intra-psychic processes are also socio-psychic. There are numerous reasons for action. 'Scholarly truth' about practices can never be reduced to a single explanatory factor. It is therefore appropriate to include in the analysis the permanent interaction between social life and psychic life. A real socio-analysis should be capable of analysing this duality and the reciprocity of influences.

Considering that actors involved in innovation networks are often present on a personal basis, outside of the context of authority and subordination (if they are employees), the inclusion of clinical sociology appears even more important. In spite of existing interdependencies, organisations employers may be less inclined to regulate the individual behaviour of employees representing them. These networks are also spaces open to new transactions between the psychic and the social dimensions in the process of 'individuation' ${ }^{2}$. In comparison, this process is difficult in more traditional organisations of bureaucratic (mechanical or professional) but also of paternalistic organisational form (numerous SMEs). These open spaces are defined by interactions between individuals who belong to various types of 'productive organisations' (individual entrepreneurs, academia, project managers of business incubators, SME directors) and benefit from financial support or subsidies. Here, the governance rules are unclear and constantly evolving; objectives are not firmly defined. They fluctuate with the actors involved in the network governance and animation bodies as well as with the projects of the actors taking part in the network activities.

The internal validity of the present research is based on the nature of data collection and processes structured according to the emergent theoretical framework of the community-based open innovation network (Yin, 2003). The research team attended the project governance meetings and took thorough notes of all discussions. They observed and video-recorded thematic workshops. Additionally, they conducted 15 semi-open interviews on the issues of governance, animation and social and economic recognition of community organisers. The persons interviewed included animators of thematic workshops and other animators working on the territory but not engaged in the project, workshop participants and the researchers initially involved in the project. The interview with the project leader was conducted in the form of narration, oral and written. The research team conducted analysis of all material produced by the project coordinators: reports, working notes, minutes of meetings and written comments. Interview structuring and data analysis were performed according to three conceptual dimensions of the community-based open innovation network: governance architecture, types of leadership in the parent project and in the thematic workshops, identities and social and economic 
recognition of contributors to the project. Scientific analysis of these data was communicated to the project governance to support strategic decisions once a month.

The external validity of the research is linked to the potential for learning from longitudinal and immersive scientific observation of a typical project of a community-based open innovation network (Stake, 1994). The results can be generalised within the limits of a small urban area characterised by the presence of a large human and social sciences university and a service-oriented local economy.

\section{Evolution of governance and leadership}

\subsection{From democratic to hybrid governance form}

The four evolution phases of the project can be characterised from the viewpoint of governance, leadership and produced outcomes, as summarised in Figure 1. The leader of the parent project acted as facilitator and mediator, using the vocabulary of Christopher about community organisers (Christopher, 1988). He was consulting and supporting the setup of the workshops. His authority position was restricted to facilitation of decisions and coordination over the overall project, contributing to conflict resolution between individuals both internally and externally, within the timeframe fixed by the local authorities. He succeeded in creating a firm management style vis-à-vis global timeframes and workshop implementation, while respecting personal agendas.

Figure 1 Characterisation of the evolution phases of the project

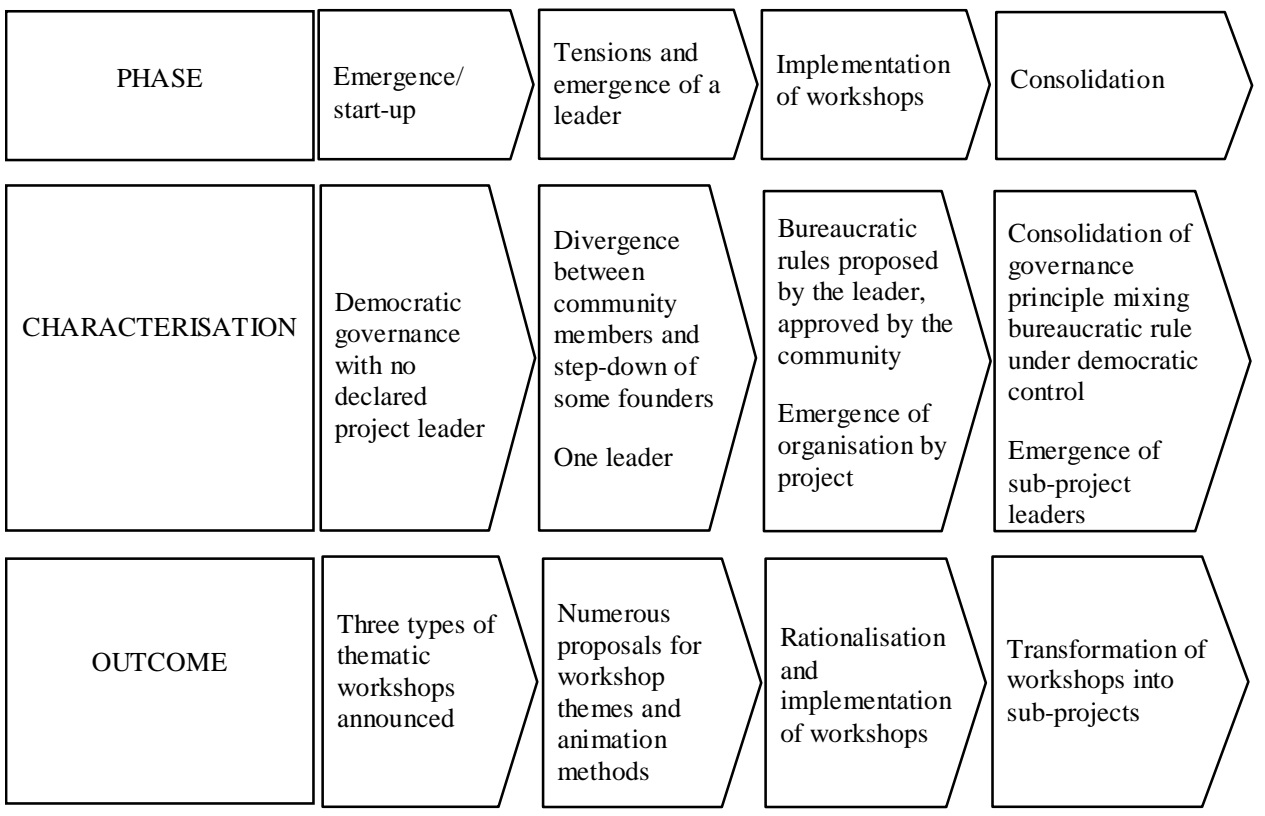

The authority of the leader relied on his technical competence and at the same time he was accountable to the community. He favoured counter-powers to gain the trust of the network members. One can characterise this form of authority as distributed social 
control. The governance architecture that emerged during the project implementation is similar to that described by O'Mahony and Ferraro: it is built on mechanisms that simultaneously enhance bureaucratic rule and democratic control (O’Mahony and Ferraro, 2007). This contrasts with difficulties in construction of a shared vision of authority described by traditional theories of organisation (Coleman, 1980; Etzioni, 1959; Harrison, 1960).

The contradiction with the warnings about the difficulty of governance design in the traditional literature on organisations (Johnson and Whyte, 1977; Rothschild and Russell, 1986; Rothschild and Whitt, 1986; Whyte and Whyte, 1988) could be rationally explained. The actors involved in the network experienced sharing authority for the first time. But conditions for collective learning were in place, paving the way for progressive construction of a consensus about the governance architecture and about the form of the parent project leadership. One can observe a retroactive loop composed of the parent project governance construction and selection of sub-project leading teams, which in turn influenced organisational design of the open innovation network. Under the effect of the combination of bureaucratic and democratic mechanisms, the parent project governance evolved simultaneously with the conception of governance within the community. Communication of the parent project coordinator with the most active network members contributed to a collective understanding of the conditions necessary for its implementation. From this viewpoint, one can consider that the construction of the open innovation network perpetuated and stabilised around narrow themes and around a core of actors. Taking the terminology of Adler, they built their collaboration on resilient trust: "high levels of informational transparency facilitate resilient trust and allow mutual adjustments in inputs, processes, and outputs as external conditions change” (Adler, 2001).

\subsection{Intellectual property, timespan and individuation process}

Three factors should be additionally taken into account in the design of a community-based open innovation network.

\subsubsection{Collective design of intellectual property and control}

In the emergence/start-up phase and in the phase of implementation of thematic workshops, each actor had to transfer part of his/her knowledge to others to create a solid pool of knowledge for open innovation. Actors who share ideas within a thematic workshop do not bring the same kind of knowledge and know-how. An important complementarity may exist between them, thus creating an opportunity for combinations of knowledge. However, some individuals are experts in a very narrow field - expertise in ICT components in the case under scrutiny. The future of the collective endeavour, organised as sub-projects within the parent project, is therefore dependent on the decisions or hesitations of the participants. The capability of experts to transfer part of their specific knowledge to their environment to support the emergence and shaping of sub-projects becomes critical. O'Mahony and West recommend clearly defining ownership proprietorship over the collectively produced content to avoid possible tensions over the collectively produced results (West, 2003; O’Mahony, 2005). The project started in uncertainty about governance and project coordination and also about control over future benefits. This uncertainty was amplified by the fact that transferable 
knowledge is a source of commercial value creation for enterprises of participating individuals. In the case of company creators, investment and knowledge pooling may be problematic because of the financial fragility of their enterprises. To tackle this problem, the parent project leader decided to compensate these actors for their expertise when the collaboration required sharing and dissemination of knowledge, the source of their enterprise know-how.

The peculiarity of the experimental project under analysis is that the individuals animating the thematic workshops were also positioned as potential sub-project leaders. This double role resulted in their non-neutrality vis-à-vis the potential outcomes of the collective brainstorming. Clarification of their role, of animation rules and of their position vis-à-vis the IPR issue should have been done at earlier stages of the experimental project.

Furthermore, to stimulate creation of new sub-projects, IPR distribution would have not necessarily been the same as in the parent project. It would have been of vital importance to define the conditions for their appropriation in advance, taking into account their nature and their participants. More specifically, questions should have been addressed as whether the sub-projects would be developed and managed by the institution managing the parent project or would be independent from this organisation and managed by the organisation of one of the community members.

\subsubsection{Collective design of planning and social schedule}

The experience under analysis underscores the importance of a long timespan for project implementation. The project was conducted in a non-bureaucratic organisational form inciting a great variety of actors belonging to outside productive organisations to work together. These diverse actors do not adjust their social and professional schedules instantaneously. Even if they operate within a small territory, geographically and politically defined, they did not plan sufficient timespan for collective learning and collective negotiations over governance, leadership and IPR.

In the short run each participant is influenced by the planning of his/her own employer. The challenge is therefore to create opportunities for a common schedule. The means is to organise the project planning over a longer run to adapt individual agendas progressively for creative moments recognised by the organisations' employers and competing with other options in individual time allocation decisions. The relatively limited timeframe for the pre-setup of the innovation lab was a real challenge for the parent project coordinator. It was neither a simple problem of timing from the project management viewpoint nor a lack of motivation from the participants of the consortium. Many workshop participants were motivated and had at their disposal means and resources to generate sub-project ideas. But in the short run they were also overtaken by professional obligations undertaken previously and conditioning their credibility and survival in their professional environment.

This rule should also concern the public action setup. A flexible timeframe in a subsidised institutional framework is a condition favouring project success.

\subsubsection{Individuation process centred on personal rather than collective skills}

Development of innovative or experimental projects is subject to socio-psychic characteristics of creative and atypical personalities. They seem to have difficulties with 
relying on the competences of other participants to construct collective skills. In the present project, suspicions extended to fears of being manipulated. The fears were rooted in the apparent vulnerability of the project governance and in the instability of the relationships among network members, leading to uncertainty about collective actions and about the emergence of sub-projects.

The question of putting into practice theoretical postulates about open innovation also remained open. More specifically, the researchers who left the consortium were unable to combine their theoretical knowledge with the practical skills of animators to create conditions for experimentation. In sum, the transition from aggregation of individual competences to construction of collective competences at the crossroads of various disciplines was problematic. The difficulty was exacerbated by the restricted planning which did not provide the time necessary for collective and organisational learning.

\section{Determinants of collaboration in sub-projects}

The experience analysed shows that different combinations of governance design and animation styles give rise to different organisational typologies and product development trajectories in emerged sub-projects. Additionally, the present study brings to the forefront the importance of animation as a profession. Facilitating speaking across social barriers in a cumulative and creative way is a form of virtuosity, a kind of expertise learned by experience and reflection about one's own experience in this area.

\subsection{Characterisation of emerged sub-projects}

In the final consolidation phase, the three workshops that emerged evolved into sub-projects. This transformation, illustrated by stabilisation of project teams, is a great achievement in the context of complete initial uncertainty and tensions about workshop themes. Table 2 classifies the emerged sub-projects based on the criteria of stakeholder diversity on the vertical axis and of the span of ICT application domains on the horizontal axis. Their combinations give rise to four types of sub-projects, synthetically described in Table 2 from the point of view of the animation style of the workshops, networking and sub-project appropriation by stakeholders, sub-project organisational form and emerged type of innovation.

The open data sub-project is situated at the intersection between high diversity of competences of workshop participants and a broadly defined ICT application domain. To succeed in taking convergent decisions, prescriptions from a simple coordination structure organised around the workshop animator appeared as an alternative solution to nurture the emergence of the sub-project. Basically, the animator sourced his pre-existing idea to the workshop participants, viewed as end-users rather than co-conceptors and later took the lead over the emerged sub-project. The simple organisational structure built around the sub-project leader replaced a potentially possible larger interdisciplinary collaborative team. The innovation was limited to import of innovative projects existent in other territories and prototyping using complementary sub-contracting relations within the local open innovation network. 
Table 2 Variety of modes of open innovation and impact on smart specialisation

\begin{tabular}{|c|c|c|c|c|c|}
\hline & & \multicolumn{4}{|c|}{ ICT application domain in thematic workshops } \\
\hline & & & Broadly defined & & Narrowly defined \\
\hline \multirow{14}{*}{ 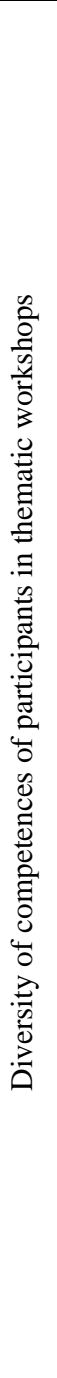 } & & & Open data sub-project & & City media sub-project \\
\hline & High & a & $\begin{array}{l}\text { Position of animator: } \\
\text { governance and IP stakeholder } \\
\text { (innovator) }\end{array}$ & a & $\begin{array}{l}\text { Position of animator: } \\
\text { governance and IP stakeholder } \\
\text { (innovator) }\end{array}$ \\
\hline & \multirow{12}{*}{ Low } & $\mathrm{b}$ & $\begin{array}{l}\text { Non-networking of actors for } \\
\text { knowledge-based development }\end{array}$ & $\mathrm{b}$ & $\begin{array}{l}\text { Networking around a specific } \\
\text { technological theme }\end{array}$ \\
\hline & & c & Project appropriation: key actor & c & $\begin{array}{l}\text { Project appropriation: citizens, } \\
\text { sponsors and consultants are } \\
\text { contributors to innovation }\end{array}$ \\
\hline & & & $\begin{array}{l}\text { involved in the project } \\
\text { conception }\end{array}$ & d & $\begin{array}{l}\text { Community, adhocratic form of } \\
\text { teams }\end{array}$ \\
\hline & & $\mathrm{d}$ & $\begin{array}{l}\text { Privileging simple structures } \\
\text { substituting interdisciplinary } \\
\text { teams }\end{array}$ & e & $\begin{array}{l}\text { Innovation centred on hack, } \\
\text { reorientation and redevelopment } \\
\text { of existing technologies }\end{array}$ \\
\hline & & e & $\begin{array}{l}\text { Import of an existing innovative } \\
\text { project and team by the territory }\end{array}$ & & \\
\hline & & Educe & tion and ICT sub-project & \multicolumn{2}{|c|}{$\begin{array}{l}\text { Strategic decision not to operate in this } \\
\text { mode of innovation }\end{array}$} \\
\hline & & $\mathrm{a}$ & $\begin{array}{l}\text { Position of animator: } \\
\text { non-governance stakeholder, }\end{array}$ & $\mathrm{a}$ & $\begin{array}{l}\text { Position of animator: strategic } \\
\text { choice not to animate }\end{array}$ \\
\hline & & b & $\begin{array}{l}\text { Networking of sub-project teams } \\
\text { by cross-prescription of a small }\end{array}$ & b & $\begin{array}{l}\text { Networking of sub-project teams } \\
\text { as a function of technological } \\
\text { constraints }\end{array}$ \\
\hline & & & number of actors & c & Project appropriation: citizens as \\
\hline & & C & $\begin{array}{l}\text { Project appropriation: expert } \\
\text { participation in project, service } \\
\text { and artefact conception, citizens } \\
\text { as beta-testers, institutional } \\
\text { infrastructure needed }\end{array}$ & d & $\begin{array}{l}\text { Simple structure of teams, } \\
\text { sometimes adhocratic combined } \\
\text { with professional bureaucracy }\end{array}$ \\
\hline & & d & Adhocratic team & e & Innovation centred on \\
\hline & & e & $\begin{array}{l}\text { Innovation centred on services } \\
\text { and social innovation rather than } \\
\text { on ICT }\end{array}$ & & market-oriented \\
\hline
\end{tabular}

In the case of the city media sub-project, the community-based network involving a great diversity of participants was organised around a narrow technological theme, defined by the animator who became the sub-project leader later. The workshop community evolved into an adhocratic organisational form, while keeping openness to a larger community. Management and project organisation were fruits of mutual and decentralised adjustments enabling inter-organisational and cross-disciplinary integration rooted in values, beliefs and common objectives. Innovation was focused on hack, re-appropriation of digital technologies and their reorientation and redevelopment, consistent with the cognitive resources of the territory. 
The education and ICT sub-project combined broadly defined ICT application domain and relatively low diversity of participant's competences. The animator of this workshop acted as educator. Refusing to take the delicate role of party enrolment and resource networking, a priori necessary for its transformation into a sub-project. In other words, the difficulty in its consolidation was related to the absence of a leader. The parent project coordinator collaborated with the animator to give prescriptions for evolution of the sub-project outside of the experimentation. This teamwork was of adhocratic nature. Innovation was less technology-intensive and collectively built on new representations of educational activity and knowledge creation in a new digital context, without recourse to expert knowledge. After the official ending of the parent project, one of the workshop participants, an expert in virtual spaces for education, decided to take the lead over the implementation of the emerged idea. Its realisation requires service conception, artefact development within the territory and user participation in urban ICT-oriented collaborative spaces.

Table 3 Animation modes in the thematic workshops

\begin{tabular}{|c|c|c|}
\hline & $\begin{array}{l}\text { Animation mode 1: 'volunteer } \\
\text { animator' (educator) }\end{array}$ & $\begin{array}{l}\text { Animation mode 2: 'specialist with } \\
\text { technical skills' (innovator) }\end{array}$ \\
\hline Characteristics & $\begin{array}{l}\text { Lack of professional animation skills } \\
\text { and of technical knowledge in the } \\
\text { area of animated workshops }\end{array}$ & $\begin{array}{l}\text { Lack of professional animation skills } \\
\text { compensated by technical skills and } \\
\text { professional experience related to } \\
\text { sub-thematic project (IT, open data) }\end{array}$ \\
\hline \multirow[t]{2}{*}{ Risks } & $\begin{array}{l}\text { Non-emergence of innovative ideas } \\
\text { within sub-thematic workshops, } \\
\text { especially if professional skills are } \\
\text { lacking and timespan is too short }\end{array}$ & $\begin{array}{c}\text { Tendency to limit the diversity of } \\
\text { workshop participants and to narrow } \\
\text { discussions for fear of losing control } \\
\text { over collectively produced IP } \\
\text { outcomes }\end{array}$ \\
\hline & $\begin{array}{l}\text { Non-emergence of a leader to } \\
\text { transform the workshop outcomes } \\
\text { into a sub-thematic project }\end{array}$ & $\begin{array}{l}\text { Innovative project ideated within } \\
\text { sub-thematic workshops does not } \\
\text { necessarily fit with cognitive } \\
\text { resources available on the territory } \\
\text { (risk of 'imported innovation’), } \\
\text { divert from smart specialisation }\end{array}$ \\
\hline \multirow[t]{2}{*}{ Advantages } & $\begin{array}{l}\text { Great openness of workshops to } \\
\text { diverse participants }\end{array}$ & $\begin{array}{l}\text { Certainty about outcomes of } \\
\text { sub-thematic workshops }\end{array}$ \\
\hline & $\begin{array}{l}\text { Emerged innovative projects } \\
\text { reinforce smart specialisation }\end{array}$ & $\begin{array}{l}\text { Results produced within a rigid } \\
\text { timeframe }\end{array}$ \\
\hline
\end{tabular}

\subsection{Modes of animation}

Two styles of animation were observed in the project under study, synthesised in Table 3. In the first configuration (the ICT and learning thematic workshop), the animator had a neutral position regarding the IPR and was not part of the parent project governance system. He was not a professional animator, was recruited on a voluntary basis and played the role of educator (Christopher, 1988). He was not accountable in terms of results to produce and did not have technical knowledge to orient discussions leading to innovative project ideas. Further, the theme of the workshop was too broadly defined, while the number and diversity of participants ready to contribute was too low. He failed to animate in a way to favour emergence of a leader who would transform the workshop 
outcomes into a sub-project. The difficulty of his mission was also exacerbated by a too short timespan. To correct this failure, the parent project leader produced specifications for another stakeholder to take over the sub-project in the future.

In the second configuration (the city media and the open data thematic workshops), animators were interested parties with respect to the IPR exploitation. They had technological skills relative to the theme of the sub-projects. In fact, animators already had pre-conceived ideas that they brought into discussions within the thematic workshops. Basically, this is sourcing a pre-existing idea to the crowd, close to the market-oriented open innovation model (Chesbrough, 2003). Such a type of leadership is defined as innovator (Christopher, 1988). Lack of animation skills as well as non-neutrality vis-à-vis IPR and outcomes undermined the initial intention of the founders to experiment with an alternative, community-centred, mode of open innovation.

This experience is compared with interviews with two professional animators working in the territory, envisaged as potential workshop animators at early stages of the project and not selected for financial reasons. Such community organisers play the role of animator and catalyst (Christopher, 1988). Interviews with them are complemented with feedbacks of different public participants in the workshops to determine factors and conditions contributing to such animation.

Animator as catalyst creates conditions conducive to effervescence of innovative ideas within collaborative workshops. Inclusiveness is seen as the most important factor and encompasses diversity of public (synonymous with possibilities of combination of knowledge), scope of workshop theme (more or less large application domain) and animation method. Diversity of public is ensured by inviting "people coming from various horizons" (a workshop participant) and by setting a workshop theme of current public concern. In this regard, the workshop thematic should be broad enough, but quite narrow at the same time to avoid dispersion in discussions. Prior consultations with participants to adapt the workshop theme to their expectations are mentioned as a good practice. With respect to animation methods, workshop atmosphere, operational organisation and animator's position are seen as important ingredients. The workshop place should be quiet and isolated from the outside world to allow participants to keep focused within the allotted timeframe. Subdividing the workshop theme into sub-themes and sub-groups and enabling simultaneous contributions to the sub-themes by means of post-its and notice boards was particularly appreciated by interviewed participants. It enables public speaking on various subjects and in a cumulative way. The art of animation consists of not only bringing each participant into the debate but also of deepening his/her thought using simple methods of traceability of individual contributions. Thus, the animator orients the public expression of the participants and, at the same time, controls for equal distribution of ideas across the audience. Coherence between theme, methodology and types of public should also be ensured. Finally, an experienced animator should be capable of listening and recognising the value of people: "the engine of all the projects, the engine of political life, civic life is much based on recognition" (Animator 1). The strength of involvement and sensitisation is therefore in the capacity of animators of a given territory to give sense, credit and proper value to the knowledge, intuitions and feelings that shape the locality. Therefore, the professional animator becomes a key actor for smart specialisation in the context of open innovation networks. 
There is no institutionalised formal educational training of animators within the territory under study; the profession is acquired practically. The animator profession has been evolving towards a complex, systemic and interdisciplinary form. It combines permanent and custom-designed monitoring of projects to be implemented, project support and elaboration of methodologies to pool diverse ideas and to transform them into real projects. Self-financed 'research and development' activities are also part of the profession, to "identify tools, or software, or methods to be invented facilitating creative voices, let's say on a given territory" (Animator 1). Interviews conducted with professional animators reveal two emerged approaches to animation. The first one is more focused on extraction and use of knowledge: "Animation is grounded in an effort to enable participants to find solutions to their difficulties" (Animator 2). The second approach is rather focused on transformation of the potential for action built up on cognitive mediation:

"Every time, there is a phase of examination of needs, of the demand that is expressed. After the conception phase we try to think about how and what added value we can bring to the project, about the idea. Afterwards, it is necessary to create methods or tools facilitating the implementation phase of the project. Last, there is a whole mode of organisation to be coordinated such that the idea ... becomes reality”. (Animator 1)

\section{Research, managerial and policy implications}

Theoretical works emphasise the importance of the capacity to transfer knowledge to external environments, building relationships and attracting other networks (Enkel and Gassmann, 2007) for the construction of an open innovation network. However, these recommendations are generic and need to be specified according to the territorial context of specialisation. We list here factors important for shaping a community-based open innovation network within a small urban territory.

The first factor deals with the governance construction. Community-based democratic functioning needs to be mixed with bureaucratic rules. The project under analysis was consolidated around a set of bureaucratic and democratic mechanisms, 'network stabilisers', ensuring that the governance architecture represented the interests of everyone and offering adaptation tools to the network system. Within this governance architecture, the community members should pay attention to factors determining collaboration and project implementation rooted in the cognitive resources of the territory: the IPR issue, the timespan and the individual and organisational characteristics of participants. In sum, the issue at stake is the existence of a community form of organisation viewed as an alternative to traditional hierarchic forms of organisation or to a quasi-market based on sub-contracting relations (Adler, 2001; Bradach and Eccles, 1989; Ouchi, 1980; Powell, 1990).

Community animation style is highlighted as the second important factor. If thematic workshops are organised and animated in a professional way, they will be conducive to the emergence and realisation of innovative ideas 'from the grassroots', i.e., perfectly matching the cognitive resources of a given territory. Intuitively, such open innovation process would be conducive to smart specialisation. The professional animator plays the role of animator and catalyst (Christopher, 1988). Innovator or educator profiles without Catalyst competences may not suffice to initiate collective innovation process 
contributing to smart specialisation. The policy implication of this finding is that local authorities should facilitate emergence of professional animators.

\section{Conclusions}

Local authorities are becoming more and more aware that collectively created knowledge and its appropriation by various stakeholders distinct from classical understanding of corporate governance, is a new source of local development affecting at the same time public services and private offer. Our research gives an insight into this issue by studying an experimental project of pre-setup of an open innovation lab in the territory of Pays d'Aix, France. Following the theoretical contributions on governance and organisation of community-based open innovation networks, this initiative is analysed from the perspective of governance, leadership and organisation of collaboration.

A list of key factors is established to favour emergence of ideas from the cognitive resources of the territory and their conversion into locally anchored innovative collaborative projects. It includes governance design, IPR negotiation, personal and organisational characteristics of community participants and a loose timeframe for ideas to come into reality. Professionalism of animators is another important issue to bring endogenous innovation based on local specific resources with a greater potential for new forms of cooperation and social wealth.

The innovation process rooted in the local territory is different from that within individual enterprises whose interest is fast acquisition and utilisation of knowledge (Carlucci et al., 2004). The two processes are complementary and both are necessary ingredients for local development. Articulation between them and the social temporality of action constitutes a new avenue for research.

\section{References}

Adler, P.S. (2001) 'Market, hierarchy, and trust: the knowledge economy and the future of capitalism', Organization Science, Vol. 12, No. 2, pp.215-234.

Argyris, C. and Schön, D.A. (1978) Organisational Learning: A Theory of Action Perspective, Addisson Wesley, Reading, Mass.

Astley, W.G. and van de Ven, A. (1983) 'Central perspectives and debates in organization theory', Administrative Science Quarterly, Vol. 28, No. 2, pp.245-273.

Bradach, J.L. and Eccles, R.G. (1989) 'Price, authority, and trust: from ideal types to plural forms', Annual Review of Sociology, Vol. 15, pp.97-118.

Burt, R.S. (1992) Structural Holes, Harvard University Press, Cambridge.

Carlucci, D., Marr, B. and Schiuma, G. (2004) 'The knowledge value chain - how intellectual capital impacts business performance', International Journal of Technology Management, Vol. 27, Nos. 6-7, pp.575-590.

Chesbrough, H.W. (2003) Open Innovation: The New Imperative for Creating and Profiting from Technology, Harvard Business School, Cambridge, Mass.

Chesbrough, H.W. and Schwartz, K. (2007) 'Innovating business models with co-development partnerships’, Research \& Technology Management, Vol. 50, No. 1, pp.55-59.

Christopher, A. (1988) Role of Community Organiser in Different Settings [online] http://www.ignou.ac.in/upload/bswe-03-block1-unit-5-small-size.pdf (accessed 22 February 2013). 
Cleempoel, M. and Wathieu, M. (2006) I Sing the Body Digital [online] http://www.rurart.org/ N/telechargements_rurart/ressources_documentaires_rurart/art_numerique_rurart/i_sing_the_b ody_digital.pdf (accessed 20 October 2012).

Coleman, J.S. (1980) ‘Authority systems’, Public Opinion Quarterly, Vol. 44, No. 2, pp.143-163.

Enkel, E. and Gassmann, O. (2007) Driving Open Innovation in the Front End, EURAM, Paris.

Etzioni, A. (1959) 'Authority structure and organizational effectiveness', Administrative Science Quarterly, Vol. 4, No. 1, pp.43-67.

Foray, D. and Goenaga, X. (2013) The Goals of Smart Specialisation, European Commission Joint Research Centre - Institute for Prospective Technological Studies, Publications Office of the European Union, Luxembourg.

Friedberg, E. (1993) Le pouvoir et la règle, Seuil, Paris.

Gaulejac, V. (2008) La sociologie clinique entre psychanalyse et socioanalyse, Sociologies, Vol. 27, [online] http://sociologies.revues.org/1713 (accessed 21 October 2012).

Gherardi, S. (2001) 'From organizational learning to practice based knowing', Human Relations, Vol. 54, No. 1, pp.131-139.

Harrison, P.M. (1960) 'Weber's categories of authority and voluntary associations', American Sociological Review, Vol. 25, No. 2, pp.232-237.

Heckscher, C. and Andler, P.S. (2006) The Firm as a Collaborative Community: Reconstructing Trust in the Knowledge Economy, Oxford University Press, New York, NY.

Jarvenpaa, S.L. and Wernick, A. (2011) 'Paradoxical tensions in open innovation networks', European Journal of Innovation Management, Vol. 14, No. 4, pp.521-548.

Jelinek, M., Romme, R. and Boland, R. (2008) 'Introduction to the special issue organization studies as a science for design : creating collaborative artefacts and research', Organization Studies, Vol. 29, No. 3, pp.317-329.

Johnson, A.G. and Whyte, W.F. (1977) 'The Mondragon system of worker production cooperatives', Industrial and Labor Relations Review, Vol. 31, No. 1, pp.18-30.

Krippendorff, K. (2006) The Semantic Turn: A New Foundation for Design, CRC Press, Boca Raton.

Markus, M.L. (2007) 'The governance of free/open source software projects: monolithic, multidimensional, or configurational?', Journal of Management and Governance, Vol. 11, No. 2, pp.151-163.

O'Mahony, S. (2005) 'Non-profit foundations and their role in community-firm software collaboration', in Feller, J.B.F. (Ed.): Perspectives on Free and Open Source Software, pp.393-413, MIT Press, Cambridge, Mass.

O'Mahony, S. and Ferraro, F. (2007) 'The emergence of governance in an open source community’, Academy Management Journal, Vol. 50, No. 5, pp.1079-1106.

Ouchi, W. (1980) 'Markets, bureaucracies, and clans', Administrative Science Quarterly, Vol. 25, No. 1, pp.125-141.

Powell, W.W. (1990) 'Neither market nor hierarchy: network forms of organization', in Cummings L.L. and Staw, B.M. (Eds.): Research in Organizational Behavior, Vol. 12, pp.295-336, Jai Press, San Francisco.

Rothschild, J. and Russell, R. (1986) 'Alternatives to bureaucracy: democratic participation in the economy’, Annual Review of Sociology, Short, J.F. (Ed.): Vol. 12, pp.307-328.

Rothschild, J. and Whitt, J.A. (1986) The Cooperative Workplace: Potentials and Dilemmas of Organizational Democracy and Participation, Cambridge University Press, New York.

Saint-Onge, H. and Wallace, D. (2002) Leveraging Communities of Practice for Strategic Advantage, Butterworth-Heinemann, St. Louis.

Sarasvathy, S. (2004) 'Making it happen: beyond theories of the firm to theories of firm design', Entrepreneurship Theory and Practice, Vol. 28, No. 6, pp.513-531.

Scott, J. (1998) Regions and the World Economy, Oxford University Press, New York. 
Stake, R. (1994) 'Case studies', in Strategies of Qualitative Inquiry, Denzin, N.K. and Lincoln, Y. (Eds.): Vol. 2, pp.86-109, Sage publications, Thousand Oaks.

Wathieu, M. (2007) Détournements, activisme et réseaux, 4, February [online] http://www.multimedialab.be/doc/projections/doc_detournements.pdf (accessed 20 October 2012).

Wenger, E. (1998) Communities of Practice Learning Meaning and Identity, Cambridge University Press, Cambridge.

West, J. (2003) 'How open is open enough? Melding proprietary and open source platform strategies', Research Policy, Vol. 32, No. 7, pp.1259-1285.

West, J. and O'Mahony, S. (2008) 'The role of participation architecture in growing sponsored open source communities’, Industry \& Innovation, Vol. 15, No. 2, pp.145-168.

Whyte, W.F. and Whyte, K.K. (1988) Making Mondragon: The Growth and Dynamics of the Worker Cooperative Complex, ILR Press, Ithaca, NY.

Xiao, Z. and Tsui, A.S. (2007) 'When brokers may not work: the cultural contingency of social capital in chinese high-tech firms', Administrative Science Quarterly, Vol. 51, No. 1, pp.1-31.

Yin, R. (2003) Case Study Research: Design and Methods, 3rd ed., 5, Sage Publications, Newbury Park.

\section{Notes}

1 Situated in the South of France and including Marseille and Nice.

2 In the sense of Norbert Elias. 